\title{
Students' Attitude to Job Performance: Intercultural Study
}

\author{
Vilmante Kumpikaite-Valiuniene ${ }^{1}$, Ewa Glinska ${ }^{2}$, Imran Aslan $^{3}$, Antonio Mihi Ramirez ${ }^{4}$
}

${ }^{1}$ Kaunas University of Technology

Gedimino st. 50, LT-44029, Kaunas, Lithuania

E-mail.vilmante.kumpikaite@ktu.lt

${ }^{2}$ Bialystok University of Technology

Ojca Tarasiuka st 2, 16-001 Kleosin/Bialystok, Poland

E-mail.e.glinska@pb.edu.pl

${ }^{3}$ Bingol University

12000- Bingol, Turkey

E-mail.iaslan@bingol.edu.tr

${ }^{4}$ University of Granada

Campus Cartuja, 18071, Granada, Spain

E-mail.amihi@ugr.es

cross $^{\text {ref }}$ http://dx.doi.org/10.5755/j01.ee.27.2.13586

Knowledge and skills of future employees should be constantly developed in order to be in line with changes, information flow, and new technologies. High unemployment rates of youth lead us to look for reasons and means to change this situation. However, university teachers in the entire world deal with students who do not care or who do not want to work every day. Therefore, this paper aims to present the results of intercultural study evaluating students' attitudes to job performance.

The research design is based on Blanchard and Thacker's (2004) Human Performance model, which includes three main factors, namely i) Motivation, ii) Knowledge, Skills and Attitudes, and iii) Environment.

The study provides insights on how students evaluate their skills, motivation and environment factors influencing their future performance in Lithuania, Poland, Spain, Turkey, Iran, Portugal and Estonia. Totally 1355 respondents participated in the poll.

The results confirm that students evaluate their task related skills, which are the most important for employers as the weakest. Basic and growth needs are the most important, and specific environment influences students more according to the study. In addition, cultural differnces among respective countries were highlighted. This survey can be useful for university teachers working with international groups in order to improve students' viewpoint on human performance at work within national and international context, and for employers to understand better new employees coming to work after graduation from universities.

Keywords: Performance, Skills, KSA, Motivation, Environment, Students, Intercultural.

\section{Introduction}

Media and studies quite often point out the discrepancy between organizations" needs for employees and the specialists prepared by universities (Lange et al., 2014). Quite often after graduation students have difficulties integrating into labor market (de Grinevica et al., 2015). Their skills are not sufficient for employers (Gile \& Campbell, 2003; Kurekova et al., 2013). According to World bank (2015) unemployment rate of youth (15-24 years old) was 16.5 percent in Turkey, 18.7 percent in Estonia, 21.9 percent in Lithuania 27.2 percent in Poland, 28.8 percent in Iran, 37.8 percent in Portugal and even 57.1 percent in Spain in 2013. It represents the necessity to develop students' skills to make them competitive in labour market. Giles \& Campbell (2003) wrote about the difference between the skills needed by employers and those that recent university graduates have. Recruiters want schools to produce graduates with "a narrow focus on the immediate skills needed for first jobs" (Trank \& Rynes, 2003, 193). In addition, national labor markets decrease and global markets are more and more spreading with challenges of cultural differences. Therefore, it is important to pay attention to students' success in their future careers, and organizations need to have competitive staff increasing organizational performance.

Each country has a different educational system and the types of education system play a critical role in teaching students and preparing them for future life. Business schools must make fundamental curriculum changes to ensure that students are provided with the knowledge, skills, and abilities (KSAs) that are needed for success in the business world. However, another problem rises here. Universities quite often deal with the problem that students do not want to learn, to work every day and to improve their skills (Bye et al., 2007; Hanckock, 2007; Debnat et al., 2007; Ruban et al., 2003; Griffin et al., 2008). Ling \& Venesaar (2015), Runiewicz-Wardyn (2014). Therefore, it is insufficiently responsive to the various needs of today's economy and society (Fulton et al., 2007).Undoubtedly, as Machin et al. (2001) study showed, there is strong relationship between qualifications, 
employment and earnings. This shows the necessity to motivate students to develop their skills and to help them in this process in order to get benefits from three sides: i) employers will have good job performers in complicated economic situation, ii) after graduation students will integrate into the labor market easily and will earn more money, and finally, iii) labor market will not suffer from youth unemployment rate so much anymore.

Traditionally employees' performance and factors influencing their performance are analyzed by such scholars as Breevaart et al. (2015), Bakker \& Bal (2010), Goodman \& Svyantek (1999), Xanthopoulou et al. (2008). Green et al. (2004) analyzed the impact of generic and basic skills on labor market. Studies in the field of managerial skills are a priority and were analyzed for many years by such scholars as Katz (1974), Analoui (1993), Peterson \& Van Fleet (2004), Guinipero et al. (2006) and others. However, there are no studies analyzing students as future performers and their attitudes. Fishbein \& Ajzen, (1975) consider that the attitudes people have toward concepts and issues determine how they will behave in various situations. This highlights a scientific problem: how could students' attitudes to job performance be identified. In order to solve this problem scientific literature analysis and empirical research were done.

The aim of the paper is identification of students' attitudes to job performance and determining differences between them in seven countries. Blanchard and Thacker's (2004) Human Performance model was used to identify students' attitudes.

These countries face with high level of youth unemployment and represent different geographical regions, such as East and South Europe and Middle Asia. Moreover, cultural differences and views are compared based on attitudes to job performance and future expectations. Objective of this study is students' attitudes to job performance.

Scientific literature analysis and a quantitative study in Lithuania, Poland, Estonia, Spain, Portugal, Turkey and Iran were used to achieve the aim. Comparison of means, regression and correlation analysis was done using Statistical Package for Social Science (SPSS).

The paper proceeds as follows. First part provides generalized theoretical background of job performance. The method section describes the research methodology. It is followed by the results of the intercultural study on students' attitude to job performance in 7 countries. The paper is finalized with the last part providing research limitations, discussion and conclusions.

\section{Theoretical Background}

According to Motowidlo (2003), this paper defines job performance as the work related activities and how well these activities were executed as the total expected value to the organization. Performance is a function, including multiple factors including employees' knowledge, abilities, motivation and beliefs (Beitler, 2005). It is very important to improve performance at individual, group, and organizational levels. Conceptual model of job performance in organization is presented in Figure 1.

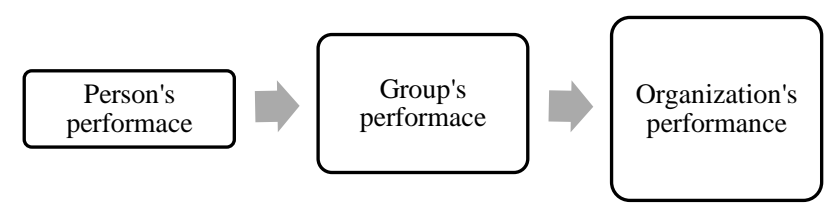

Figure 1. Conceptual model of job performance in organization

Leonard's et al. (1999) proposed job characteristics model involves four components, such as core job characteristics, critical psychological states, personal and work out-comes, and growth-need strength. People should have knowledge, skills and abilities to perform successfully. However, these elements could be insufficient for successful performance. Therefore, the primary task facing a manager is motivating employees to perform to the best of their ability (Moorhead \& Griffin, 1998). Motivation arises from people's needs and their beliefs about how best to satisfy those needs. Moreover, even this could be not enough to get the best results. There are different physical surroundings and individual factors in which performance must occur, including barriers and aids to performance, as well as objects and events. These factors could be called as environment that affects employees' performance. Therefore, to sum up all that we can present a performance equation (see equation 1) in the following form (Blanchard \& Thacker, 2004; and Beitler, 2005).

\section{Performance $=$ KSAs + Motivation + Environment (equation 1)}

With presumption that university students will take managerial position in the organization, typologies of managerial skills, such as Katz's (1974), Analoui (1993), Charalambos' et al. (2007), Whetten \& Cameron (2002), Peterson \& Van Fleet (2004), Guinipero et al. (2006) were analyzed and the following skills used in this study were highlighted: task-related, people-related, self-related and anlytical.

More specifically, Stretton (1994), Locke \& Latham (1990), Shoura \& Singh (1999) analyzed Maslow's theory in the workplace of workers who are high up the management structure within their organization. Based on previous studies, Maslow's (1967) and Wahba \& Bridwell (1976) classifications of needs were used in the following study, involving basic, social and growth needs in order to reach the aim.

According to Hatch \& Cunliffe (2006) and Daft (1997), the organizations' environment could be divided into general and specific environment. The general environment includes the broad economic, political/legal, socio-cultural, demographic, technological and global conditions that may affect their studies and future job.

\section{Method}

Research context. Summarizing the analyzed literature, Analoui's (1993) skills description, Wahba \& Bridwell's (1976) and Maslow's motives, and the environment by Daft's (1997) were used to evaluate students' attitudes to job performance according to Blanchard \&Thacker (2004) model. Conceptual research model is presented in Figure 2. 
Based on the theoretical analysis and proposed model, the following research questions were formulated:

RQ1. How do students evaluate their skills needed for future job performance?

RQ2. What motives do motivate students in the future job performance?

RQ3. How do students evaluate environments' impact on their future job performance?

RQ4. How do all these items vary according to respondents' gender, age and country?

RQ5. What is the relation between all constructs and the students' willingness to perform the work nominated as well as possible, despite received salary?

Statistical analysis was run using SPSS, including Cronbach Alfa, cluster, correlation (Spearman's correlation coefficient), one way ANOVA test and t-test for independent samples. Cluster analysis was used to check if divided criteria of every three main groups fell into correct groups, as was grouped based on theoretical analysis. Spearman's correlation was employed for criteria analysis according to gender, age and country.

Sampling method and data collection. Online survey was selected due to high Internet usage level among students. However, printed questionnaires were used in Estonia and Portugal. Questionnaires were prepared in the native language of respondents using double translation technique. It was used scale of 4 , where 0 means "not important at all", 3 - "very important" in case of motives and environment and 0 means - "weak", and 4-"very well" in case of skills evaluation.

Cronbach Alfa was used to check validity of this instrument. The instrument is valid as Cronbach Alfa index is 0,837 for motivation group, 0,861 - for skills group, and 0,709 for general environment group, which includes political, economic and governmental educational policy. Specific environment's factors were excluded from analysis, as they are heterogenic and independent.

Convenient sampling was used to run the study. 1355 students from seven countries studying business, management or administration participated in the study. $46.2 \%$ of them were male.

Sample characteristics. Regarding other characteristics, the biggest number of students were from Turkey (436, $47.7 \%$ male), following from Lithuania (322, $41.9 \%$ male), Poland (208, $44.2 \%$ male), Iran (193, $53.4 \%$ male), Spain $(127,34.6 \%$ male), Portugal $(35,65.7 \%$ male) and Estonia (34, $61.8 \%$ male). Analyzing the year of study, respondents' distribution was as follows: $27.6 \%-1^{\text {st }}$ year, $45.1 \%-2^{\text {nd }}$ year, $12.2 \%-3^{\text {rd }}$ year, $14.5-4^{\text {th }}$ and $0.4 \%$ of $5^{\text {th }}$ year.

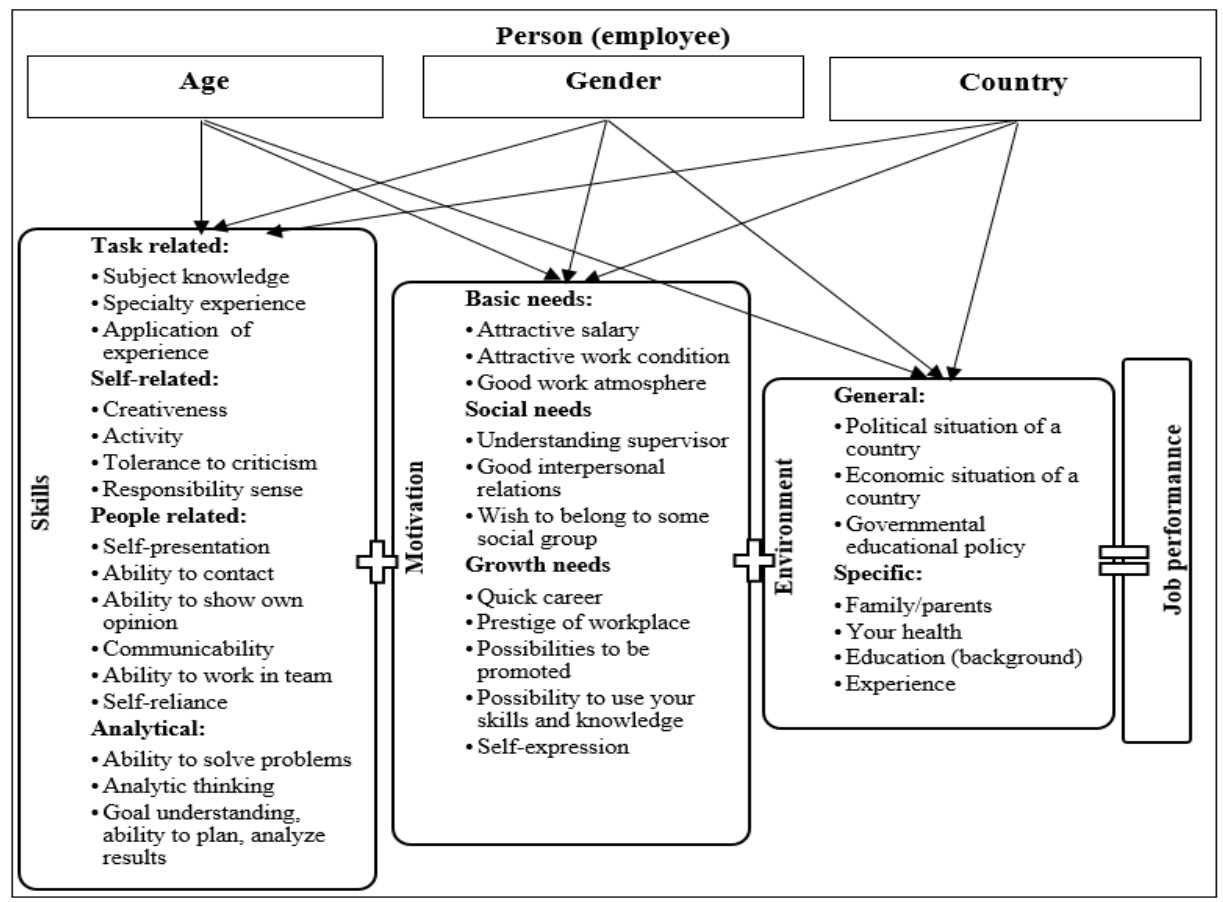

Figure 2. Conceptual model of students' attitudes evaluation

\section{Results}

At the beginning of this study, the focus was on the relations among students' willingness to perform the work nominated as well as possible, despite received salary. The model (see equation 2) was calculated, using regression analysis and it is significant with sig. $<0.05$ value.

Willingness... $=1.28+0.197 *$ skills $+0.153 *$ environment (equation 2)
Answering to RQ5, results showed that motives do not influence this willingness. Skills and environment have a positive effect on carrying out the work nominated. Moreover, the effect of skills is higher than environment. This model states that improving the skills of students and environment stimulate them to work better.

Study's results according to the three performanceinfluencing components are presented further in this paper. 


\section{Skills}

\section{General results}

Students taking part in the study were asked to assess their skills in the context of finding desired employment after obtaining a degree. The survey questionnaire presented 16 abilities which in turn were divided into 4 groups: task related, people related, analytical and selfrelated. The research results indicate (see Table 1) that students rated their people related studies the highest. The largest average scores in this group of skills were attained by the ability to work in a team (mean score of 2.42), the ability to make contacts (2.41), self-reliance (2.36), and the ability to express their own opinion (2.36). Analytical abilities, those that could help with gaining good employment in the future, were rated relatively high but lower than people related skills. Within this group, the abilities, which attained highest scores, included sense of responsibility (mean score of 2.43) and understanding of goals, the ability to plan, and the ability to analyze results (score of 2.29). Students rated their self-related abilities as well developed but less so than skills classified into groups mentioned above. In this category of abilities activity gained the highest mean score (2.21). The students' assessments showed that they judged their preparedness for future employment in the context of task related skills as being the lowest. The average score of all three skills in this group: subject specialized knowledge, experience and application of experience oscillated around the value of 2.0, while specialty experience was ranked the lowest.

The Spearman's correlation analysis highlighted skills evaluation differences according to gender. Females evaluated communicability $(\mathrm{r}=.075, \mathrm{p}=0.01)$, selfpresentation $(\mathrm{r}=.065, \mathrm{p}=0.01)$, ability to contact $(\mathrm{r}=.070$, $\mathrm{p}=0.01)$, ability to work in teams $(\mathrm{r}=.111, \mathrm{p}=0.05)$, tolerance to criticism ( $\mathrm{r}=.096, \mathrm{p}=0.05)$, and activity $(\mathrm{r}=.094, \mathrm{p}=0.05)$ higher as males. At the same time boys evaluated specialty experience $(\mathrm{r}=.183, \mathrm{p}=0.05)$, and analytical thinking $(\mathrm{r}=.075, \mathrm{p}=0.05)$ better than girls. Analyzing differences according to respondents' age, it was found that older respondents evaluate their ability to show their own opinion $(\mathrm{r}=-.069, \mathrm{p}=0.01)$, ability to work in team $(\mathrm{r}=-.057, \mathrm{p}=0.01)$, creativeness $(\mathrm{r}=-.055, \mathrm{p}=0.01)$ and tolerance to criticism ( $\mathrm{r}=-.117, \mathrm{p}=0.05)$ worse than younger ones. In addition, just one older respondents' evaluation for responsibility sense $(\mathrm{r}=.072, \mathrm{p}=0.01)$ is higher in comparison with younger respondents.

Table 1

Evaluation of skills - mean values

\begin{tabular}{|c|c|c|c|c|c|c|c|c|c|c|c|c|c|c|c|c|}
\hline & \multicolumn{3}{|c|}{ Task related } & \multicolumn{6}{|c|}{ People - related } & \multicolumn{3}{|c|}{ Analytical } & \multicolumn{4}{|c|}{ Self-related } \\
\hline Skills & 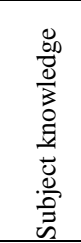 & 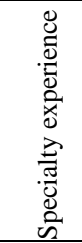 & 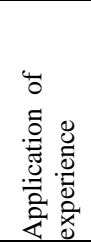 & 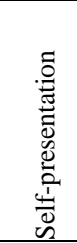 & 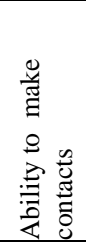 & 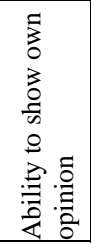 & 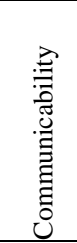 & 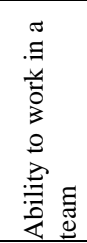 & 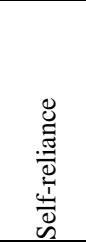 & 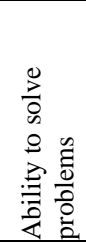 & 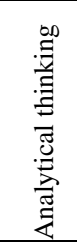 & 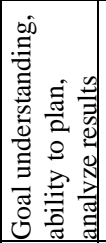 & 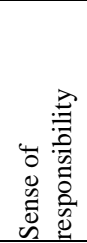 & 岕 & 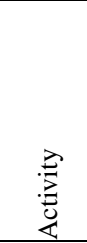 & 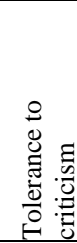 \\
\hline Mean & 1.97 & 1.54 & 2.05 & 2.06 & 2.41 & 2.36 & 2.33 & 2.42 & 2.36 & 2.24 & 2.15 & 2.29 & 2.43 & 2.18 & 2.21 & 2.15 \\
\hline $\mathrm{N}$ & 1280 & 1291 & 1287 & 1264 & 1289 & 1244 & 1253 & 1281 & 1270 & 1272 & 1267 & 1258 & 1268 & 1269 & 1269 & 1255 \\
\hline $\begin{array}{l}\text { Std. } \\
\text { Deviation }\end{array}$ & 0.917 & 1.078 & 0.886 & 0.841 & 0.805 & 0.805 & 0.801 & 0.833 & 0.852 & 0.761 & 0.857 & 0.812 & 0.856 & 0.842 & 0.854 & 1.101 \\
\hline Mean & \multicolumn{3}{|c|}{1,85} & \multicolumn{6}{|c|}{2,32} & \multicolumn{4}{|c|}{2,28} & \multicolumn{3}{|c|}{2,18} \\
\hline
\end{tabular}

Comparison of groups of students from respective countries

In respect to judging, which skills are essential for gaining desired job after finishing college there are relatively clear differences between groups of students from respective countries (see Table 2).

Most and least important skills by country

\begin{tabular}{|l|l|l|l|l|}
\hline \multicolumn{1}{|c|}{$\begin{array}{c}\text { Students' } \\
\text { country of origin }\end{array}$} & \multicolumn{3}{|c|}{ The most important skills } \\
\hline Lithuania & $\begin{array}{l}\text { tolerance to criticism } \\
(2.47)\end{array}$ & ability to work in a team (2.30) & $\begin{array}{l}\text { goal understanding, ability to } \\
\text { plan, analyze results (2.26) }\end{array}$ & specialty experience (1.37) \\
\hline Turkey & $\begin{array}{l}\text { sense of responsibility } \\
(2.58)\end{array}$ & $\begin{array}{l}\text { ability to show own opinion } \\
(2.39)\end{array}$ & communicability (2.35) \\
\hline Iran & $\begin{array}{l}\text { sense of responsibility } \\
(2.46)\end{array}$ & ability to make contacts (2.42) & self-presentation (2.38) & specialty experience (1.19) \\
\hline Spain & $\begin{array}{l}\text { ability to make contacts } \\
(2.88)\end{array}$ & $\begin{array}{l}\text { goal understanding, ability to } \\
\text { plan, analyze results (2.83). }\end{array}$ & subject knowledge (2.67) & application experience (1.59) \\
\hline Portugal & responsibility sense (2.85) & subject knowledge (2.74) & application experience (2.69) & tolerance to criticism (2.18) \\
\hline Estonia & $\begin{array}{l}\text { ability to show own } \\
\text { opinion (2.53) }\end{array}$ & communicability (2.40) & $\begin{array}{l}\text { ability to work in a team } \\
(2.40)\end{array}$ & application of experience (2.47) \\
\hline Poland & $\begin{array}{l}\text { sense of responsibility } \\
(2.50)\end{array}$ & sommunicability (2.41) & tolerance to criticism (1.82) \\
\hline
\end{tabular}

Skills rated the highest by students from Lithuania are tolerance to criticism, ability to work in a team, and understanding goals, the ability to plan, the capacity to analyze results. Students from Turkey and Iran rate their sense of responsibility as the most important. Turkish students also feel that they are additionally well prepared for future employment by exhibiting the ability to show their own opinion and communicability, while Iranian 
students poses the ability to make contacts and selfpresentation, all people related skills. When it comes to Spanish students, they value their ability to make contacts and understanding goals. Students from Spain were the only group of respondents who also highly value their subject knowledge (part of task related skills). Looking at the responses given by Estonian students high marks for people related skill are evident. Polish students rate sense of responsibility the highest (analytical skills). It is interesting that this group also highly values their selfreliance in relation to students from other countries.

The lowest ratings given by respondents from Lithuania, Turkey and Iran fell to specialty experience. Students from Estonia and Spain gave the lowest scores to their ability to apply experience, while Polish and Portuguese students felt their tolerance of criticism was their weakest point. Moreover, all groups are significantly different according to ANOVA test with sig. $<0.005$ value. The lowest differences are seen in skills group by Tukey. This group has significant differences with Iran and Poland with less mean.

\section{Motivation}

\section{General results}

Students participating in the study were asked to indicate the importance of individual factors concerned with motivation in their future workplace. Elements, which were considered during the compilation of a list of motivational factors included those meeting basic needs and social needs as well as the need for growth and selfdevelopment. Motivational factors were divided into groups. The first set contained an attractive salary and attractive working conditions while the second consisted of good work atmosphere, an understanding supervisor, good interpersonal relations and the wish to belong to some social group. The third group of factors incorporated a quick career, prestige of a workplace, possibility to be promoted, possibility to use your skills and knowledge as well as self-expression. Importance of these elements in a future workplace, as well as the mean values of answers chosen by all students participating in the study have been presented in Table 3.

Table 3

Importance of motivational factors - mean values

\begin{tabular}{|c|c|c|c|c|c|c|c|c|c|c|c|}
\hline & \multicolumn{2}{|c|}{ Basic needs } & \multicolumn{4}{|c|}{ Social needs } & \multicolumn{5}{|c|}{ Growth needs } \\
\hline & 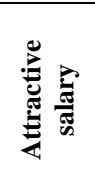 & 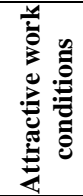 & 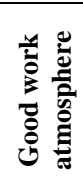 & 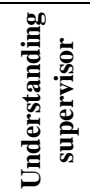 & 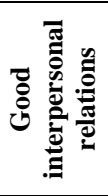 & 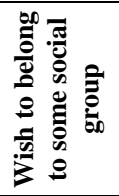 & 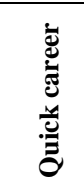 & 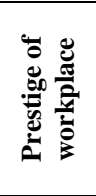 & 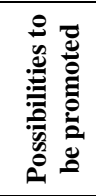 & 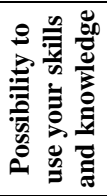 & 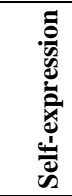 \\
\hline $\begin{array}{l}\text { Total mean } \\
\text { value }\end{array}$ & 2.57 & 2.62 & 2.65 & 2.46 & 2.52 & 1.82 & 2.11 & 2.20 & 2.50 & 2.64 & 2.56 \\
\hline $\mathrm{N}$ & 1260 & 1257 & 1253 & 1234 & 1239 & 1244 & 1245 & 1245 & 1212 & 1234 & 1231 \\
\hline $\begin{array}{l}\text { Std. } \\
\text { Deviation }\end{array}$ & 0.671 & 0.657 & 0.662 & 0.741 & 0.760 & 0.939 & 0.904 & 0.910 & 0.809 & 0.717 & 0.736 \\
\hline Mean & \multicolumn{2}{|c|}{2,59} & \multicolumn{4}{|c|}{2,36} & \multicolumn{5}{|c|}{2,40} \\
\hline
\end{tabular}

Looking at the average scores produced by the students, material aspects (those fulfilling basic needs) connected with future work turned out to be the most important group of motivational factors. Interestingly, attractive working conditions were rated higher than the level of future earnings.

The results of the research showed that within the group of social motivational factors the element connected with good working atmosphere (mean score of 2.62 ) as well as the related factor of good interpersonal relations at work (average of 2.52) were especially highly regarded. Another social motivational factor, which was a very significant motivator for students, was to have an understanding supervisor (average score of 2.46). The notion of wishing to belong to some social group turned out to have less relevance to participants (an average of 1.82).

The third group of factors influencing the students' motivation toward employment included those elements connected with fulfilling their need for self-development. Within this group of factors a very significant role in

motivating the students at work was played by the possibility to use your skills and knowledge (a score of 2.64) as well as the ability to express yourself through the realization of working tasks (average score of 2.50). Less important, but still relatively significant for students, were such factors as a quick career and prestige of a workplace.
These elements were considered by students as relevant but not the most imperative in shaping their attitudes toward a future professional occupation. Average scores attained by these factors were 2.11 and 2.20 respectively.

To look at differences according to gender, Spearman's correlation analysis was used. Statistical differences were found in evaluating understanding supervisor $(\mathrm{r}=.071$, $\mathrm{p}=0.01)$, attractive work conditions $(\mathrm{r}=.074, \mathrm{p}=0.05)$, selfexpression $(\mathrm{r}=.082, \mathrm{p}=0.05)$, good work atmosphere $(\mathrm{r}=.076, \mathrm{p}=0.05)$, good interpersonal relations $(\mathrm{r}=.092$, $\mathrm{p}=0.05)$, wishing to belong to some social group $(\mathrm{r}=.088$, $\mathrm{p}=0.05)$, and possibilities to be promoted $(\mathrm{r}=.077, \mathrm{p}=0.05)$. Females' evaluations were higher than males in all these cases. Therefore, it let to think that human factors and motivation generally is more important for girl-students.

Results according to age highlighted differences among all motives except attractive salary. It demonstrates that younger respondents are more motivated by all motives in comparison with older ones and in addition, attractive salary is important for all age groups of respondents.

Comparison of Groups of Students from Respective Countries

Analyzing the contrast in importance assigned by students to individual motivational factors toward future employment, clear differences can be seen in answers 
given by students from various countries (see Table 4). Students from Poland, Lithuania, Portugal and Estonia admitted that they would find their motivation for work in economic factors connected to attractive work conditions and salaries. According to them a good atmosphere at work, one of social motivational elements, plays an important role in building workplace motivation but is not as relevant as those factors related to finances. Lithuanian students also mention the possibility to use one's skills and knowledge as a factor that is as important as a good workplace atmosphere in the process of shaping their attitudes toward a workplace. Students from Iran are motivated by factors which fulfill their basic needs (attractive working conditions - an average score of 2.79), social elements (good workplace atmosphere - mean score 2.73) as well as by those fulfilling their need for selfexpression (average score 2.73). This group of students also points to the very significant role of having an understanding supervisor (2.73) in forming their attitude toward a future workplace. Students from Turkey and Spain admitted that they are motivated by those factors, which satisfy their higher needs such as self-expression, the possibility to use their skills and knowledge and the social element of a good atmosphere at the workplace.

Table 4

Most and least important motivational factors by country

\begin{tabular}{|c|c|c|c|c|}
\hline $\begin{array}{l}\text { Students' } \\
\text { country } \\
\text { of origin }\end{array}$ & \multicolumn{3}{|c|}{$\begin{array}{l}\text { The most important motivational factors } \\
\text { (mean values) }\end{array}$} & $\begin{array}{c}\text { The least important motivational } \\
\text { factors } \\
\text { (mean values) }\end{array}$ \\
\hline Lithuania & $\begin{array}{l}\text { attractive work } \\
\text { conditions }(2.66)\end{array}$ & attractive salary (2.63) & $\begin{array}{l}\text { good work atmosphere }(2.60) \\
\text { possibility to use your skills and } \\
\text { knowledge }(2.60)\end{array}$ & $\begin{array}{l}\text { wish to belong to some social group } \\
(1.55)\end{array}$ \\
\hline Turkey & self-expression (2.74) & $\begin{array}{l}\text { good work atmosphere } \\
(2.69)\end{array}$ & $\begin{array}{l}\text { possibility to use your skills and } \\
\text { knowledge }(2.65)\end{array}$ & $\begin{array}{l}\text { wish to belong to some social group } \\
(1.93)\end{array}$ \\
\hline Iran & $\begin{array}{l}\text { attractive work } \\
\text { conditions }(2.79)\end{array}$ & $\begin{array}{l}\text { good work atmosphere } \\
(2.74)\end{array}$ & $\begin{array}{l}\text { self-expression (2.73) } \\
\text { understanding supervisor }(2.73)\end{array}$ & $\begin{array}{l}\text { wish to belong to some social group } \\
(2.12)\end{array}$ \\
\hline Spain & $\begin{array}{l}\text { possibility to use your } \\
\text { skills and knowledge } \\
(2.97)\end{array}$ & $\begin{array}{l}\text { good interpersonal } \\
\text { relations }(2.92)\end{array}$ & self-expression (2.72) & understanding supervisor (1.98) \\
\hline Portugal & attractive salary (2.83) & $\begin{array}{l}\text { attractive work conditions } \\
(2.54)\end{array}$ & self-expression (2.51) & $\begin{array}{l}\text { wish to belong to some social group } \\
(1.60)\end{array}$ \\
\hline Estonia & attractive salary (2.55) & $\begin{array}{l}\text { attractive work conditions } \\
(2.47)\end{array}$ & good work atmosphere (2.38) & quick career (1.62) \\
\hline Poland & attractive salary (2.69) & $\begin{array}{l}\text { attractive work conditions } \\
(2.66)\end{array}$ & good work atmosphere (2.54) & $\begin{array}{l}\text { wish to belong to some social group } \\
(1.19)\end{array}$ \\
\hline
\end{tabular}

\section{Environment}

\section{General results}

Respondents were asked to identify those factors which, being elements of the environment in which they live, influence their job performance (see Table 5). The highest average result from among seven factors given (health, family/parents, governmental educational policy, economic situation of a country, political situation of a country, education, experience) was attained by the element of health (average of 2.63, table 1). The second factor which was considered as having a high impact on the students' attitude toward work was family (average of 2.37). Less crucial, yet still very significant in shaping attitudes toward work, were such factors as educational (background) and the country's economic situation, both of which gained the same average score (2.24). Relatively important but chosen less often in regards to influencing attitudes toward a workplace turned out the element of experience (average score of 2.08). Governmental educational policy (average score of 1.95) and the country's political situation (average score of 1.78) were the lowest rated factors in regards to workplace performance. Comparing specific and general environments' means, we can see that specific environment is more important for respondents.

Comparing results by gender, it was found that females again evaluated some factors as more important in comparison with males. Just between two factors, such as health and family/parents no statistical differences were found.

However, looking at differences according to age, younger respondents evaluated economic situation of the country $(\mathrm{r}=-.110, \mathrm{p}=0.05)$, political situation of the country $(\mathrm{r}=-.122, \mathrm{p}=0.05)$, government's educational policy $(\mathrm{r}=-$ $.086, \mathrm{p}=0.05)$ and educational background $(\mathrm{r}=-.096$, $\mathrm{p}=0.05)$ significantly more important than older students. It shows that younger students think that general environment could have more impact on their future job. In addition, they value a diploma more than older respondents for their future job also.

Importance of environment factors - total mean values

\begin{tabular}{|c|c|c|c|c|c|c|c|}
\hline \multirow[b]{2}{*}{ Factors } & \multicolumn{4}{|c|}{ Specific } & \multicolumn{3}{|c|}{ General } \\
\hline & $\begin{array}{l}\text { Your } \\
\text { health }\end{array}$ & Family/parents & $\begin{array}{c}\text { Education } \\
\text { (background) }\end{array}$ & Experience & $\begin{array}{c}\text { Economic situation of } \\
\text { a country }\end{array}$ & $\begin{array}{l}\text { Political situation } \\
\text { of a country }\end{array}$ & $\begin{array}{c}\text { Government's } \\
\text { educational } \\
\text { policy }\end{array}$ \\
\hline $\begin{array}{l}\text { Mean } \\
\text { value }\end{array}$ & 2.63 & 2.37 & 2.24 & 2.08 & 2.24 & 1.78 & 1.95 \\
\hline $\mathrm{N}$ & 1280 & 1285 & 1147 & 1246 & 1283 & 1282 & 1283 \\
\hline $\begin{array}{l}\text { Std. } \\
\text { Deviation }\end{array}$ & 0.693 & 0.919 & 0.0852 & 1.053 & 0.974 & 0.969 & 0.957 \\
\hline Mean & \multicolumn{4}{|c|}{2.33} & \multicolumn{3}{|c|}{1.99} \\
\hline
\end{tabular}




\section{Comparison of Students from Particular Countries}

Health was the most important environmental factor influencing attitudes toward future work nearly for every group of students taken into account in the study (table 6). Only students from Poland chose education as the most important environmental factor (however, in this case health was a close second). Family was the second most important factor for students from Turkey, Iran, Portugal and Estonia. This factor was not chosen by Polish students as one of the first three environmental elements which would influence their future employment. The third most important environmental factor differed for groups of students representing various countries. In the opinion of Turkish students government's educational policy was a very important issue influencing attitudes toward work, while for students from Lithuania an important role in shaping their approach toward work which they will perform in the future was played by the country's economic situation. Both Polish and Turkish students also stressed the importance of experience in forming their approach toward employment.

According to the opinions of students from all countries, the least important factor in building attitudes toward future workplaces was political situation of a country.

Importance of environmental factors by country

\begin{tabular}{|c|c|c|c|}
\hline Students from: & \multicolumn{3}{|c|}{$\begin{array}{c}\text { The most important factors of environment } \\
\text { (mean values) }\end{array}$} \\
\hline Lithuania & your health (2.47) & education (background) (2.40) & economic situation of a country (2.04) \\
\hline Turkey & your health (2.64) & family/parents (2.57) & $\begin{array}{l}\text { government's educational policy } \\
\text { experience }(2.25)\end{array}$ \\
\hline Iran & your health $(2.68)$ & family/parents (2.48) & education (background) (2.30) \\
\hline Spain & economic situation of a country (2.65) & family/parents (2.60) & \multirow{3}{*}{$\begin{array}{l}\text { other factors attained an average mark lower than } \\
2\end{array}$} \\
\hline Portugal & your health $(2.30)$ & family/parents (2.10) & \\
\hline Estonia & your health $(2.39)$ & family/parents (2.23) & \\
\hline Poland & education (background) (2.60) & your health $(2.52)$ & experience (2.49) \\
\hline
\end{tabular}

Using Anova analysis (see Table 7), we can see that Spain, Turkey and Iran fall in the same group according to the environment.

Whereas Lithuania and Poland have more similarities and fell into another group. However, it is interesting that Portugal, being a neighbouring country to Spain, and Estonia being in the same region as Lithuania, do not fit in the same grouping as these countries. It could be because the group sizes are unequal.

Table 7

Grouping of countries by Environment

\begin{tabular}{|c|c|c|c|c|c|c|}
\hline \multirow{2}{*}{ Country } & \multirow[b]{2}{*}{$\mathbf{N}$} & \multicolumn{5}{|c|}{ Subset for alpha $=0.05$} \\
\hline & & 1 & 2 & 3 & 4 & 5 \\
\hline $\begin{array}{l}\text { Portugal } \\
\text { Estonia }\end{array}$ & 20 &, 7500 & 12710 & & & \\
\hline Lithuania & 303 & & $1,5 / 10$ & 1,9356 & & \\
\hline Poland & 205 & & & 2,0228 & 2,0228 & \\
\hline Spain & 127 & & & & 2,1995 & 2,1995 \\
\hline Turkey & 436 & & & & & 2,2620 \\
\hline Iran & 194 & & & & & 2,3226 \\
\hline
\end{tabular}

Means for groups in homogeneous subsets are displayed.

a. Uses Harmonic Mean Sample Size $=66,188$.

b. The group sizes are unequal. The harmonic mean of the group sizes is used. Type I error levels are not guaranteed.

\section{Discussion and conclusions}

General results of the study identified (RQ1) that students evaluate their task related skills the worst and people related skills the best. In addition, basic needs and specific environment were highlighted as the most important for students in comparison with other factors.

Debnath et al. (2007) discussed designing business school courses to develop students' motivation and concluded that the instructors' own innovations, experience, and different resources, such as cases, exercises or simulation games, therefore they can organize strong courses to make impact on the students' motivation. This could help enhance development of skills, especially task related, which were evaluated the worst in conducted study.

Comparing survey's results according to countries, age and gender (RQ4) some differences were highlighted. For example, Lithuanians are the most tolerant to criticism and their evaluation was the highest and the same value was the lowest for Poland and Portugal respondents. Furthermore, results revealed that females pay more attention to human factors, people-related skills, and are more reacting to environmental factors.

Results showed that evaluating environmental factors (RQ3) as the main factor, respondents' health was depicted. Family was the second important factor. However, Estonians and Lithuanians did not mention this factor among the most important. It looks like it could be explained by cultural differences, when families do not influence students' performance so much. However, it is a bit strange, because family-children relations are quite close and connected all their life. In addition, Spanish evaluated economic situation of the country as the most important environmental factor influencing their future performance. This is not surprising because, due to the prolonged economic crisis, the unemployment rate became one of the highest in the EU for the past several years, and even for a good specialist it is very hard to find a job and to be employed.

All highlighted results could be explained because of countries' and explored groups' particularities. For example, countries like Iran are more closed to international competition and they mainly depend on natural resources, thus the main employment provider is government. Government jobs are the main way of earning a living in these kinds of countries like Iraq or Saudi Arabia. Estonia and Lithuania have not high value natural 
resources. Thus, students in these countries seek jobs within the country or in the EU where there is a strong competition based on skills and trainings. Surveyed students from Turkey are from the provinces in East Turkey. In this region the situation is worse in terms of finding a job, and people mainly depend on government jobs or jobs in agriculture where no any training or special requirements are needed. However, this group could be quite different if students were from the West of Turkey. Moreover, many students who graduate from schools in the East of Turkey go to other developed cities in Turkey and they have to compete with their peers who graduated from universities in big cities.

More specifically, Maslow (1967) believed, that older adults were generally more likely than younger adults to be concerned with higher motivation. This assumption was not confirmed in this study. However, it could be explained because of young respondents' age in this study. It varied in very small scale. 39.2 percent of respondents were 20 years and younger, 59.9 percent - 21-30 years old and others were older. Therefore, this age scale is too small to see difference among needs' changes. Keeping in mind that respondents were young, it corresponds with Maslow's view of lower needs importance for younger people. Moreover, it seems understandable, that young people seeking freedom and independence from families seek to get more money. Attractive salary (RQ2) was selected as the most important for Portuguese, Estonians, Polish and Lithuanians.

Undoubtedly, job performance is very important issue for organizations, universities and students in nowadays' economic situation as well. Summarizing, it could be said that received results could be useful for university teachers as well as for practitioners to be more familiar with students' motives for performance, to help in their skills' development and avoidance of environmental factors.

\section{Limitations and Guidelines for Future Research}

As the first limitation, convenient sample of respondents could be highlighted. In majority cases students are from one university in every country, except Turkey and Lithuania. Such samples do not represent geographical distribution of respondents inside the countries. As other limitation, group sizes are unequal. Small sample of respondents from Estonia and Portugal in comparison with other groups should be mentioned. Therefore, it could misrepresent results of this research. Moreover, students of different study year participated in this survey. This could influence received results as well. It remains unclear why evaluations by Portuguese respondents' group were higher in comparison with others. In addition, cultural differences among evaluations were found. However, the reasons of differences were not analyzed. The paper aimed to present the main results of the study, therefore literature analysis is not presented in detail in this paper.

The authors will seek to make multiple survey and to compare how results changed in time prospect in future studies. Moreover, it would be interesting to involve more countries for similar comparison analysis with bigger samples from all countries and to pay more attention to countries' cultural differences.

\section{References}

Analoui, F. (1993). Skills of management. In J. W.Cusworth \& T. F. Franks (Eds), Managing Projects in Developing Countries. Longman.

Bakker, A. B., \& Bal, P. M. (2010). Weekly work engagement and performance: a study among starting teachers, Journal of Occupational and Organizational Psychology, 83(1), 189-206. http://dx.doi.org/10.1348/096317909X402596

Beitler, M. (2005). Strategic organizational learning: a Practitioner's Guide for Managers and Consultants. Chapter 2, Motivation, Learning, \& Development. http://www.mikebeitler.com/freestuff/Strategic-Organizational-LearningChapter-2.pdf

Blanchard, P. N., \& Thacker, J. W. (2004). Effective training: Systems, strategies, and practices (2nd ed.). Upper Saddle River, NJ: Pearson/Prentice Hall.

Breevaart, K., Bakker, A. B. Demerouti, E., \& van den Heuvel, M. (2015). Leader-member exchange, work engagement, and job performance, Journal of Managerial Psychology, 30(7), 754-770 Permanent link to this document: DOI: http://dx.doi.org/10.1108/JMP-03-2013-0088

Bye, D., Pushkar, D., \& Conway, M. (2007). Undergraduate Students Motivation, Interest, and Positive Affect in Traditional and Nontraditional. Adult Education Quarterly, 57(2), 141-158. http://dx.doi.org/10.1177/0741713606294235

Daft, L. R., \& Weick, K. E. (1984). Toward a Model of Organizations as Interpretation Systems. Academy Management Review, 9(2), 284-295, DOI:10.5465/AMR.1984.4277657

Debnath, S., Tandon, L., V., \& Pointer, L. V. (2007). Motivation: An Application of the Job Characteristics Model Designing Business School Courses to Promote Student. Journal of Management Education, 31, 812-835. http://dx.doi.org/10. $1177 / 1052562906290914$

Fishbein, M., \& Ajzen, I. (1975). Belief, attitude, intention and behavior: An introduction to theory and research. Reading, MA: Addison-Wesley.

Fulton, O., Santiago, P., Edquist,Ch., El-Khawas, E., \& Hackl, E. (2007). OECD Reviews of Tertiary Education. Poland. OECD Publishing. 
Giles, L. \& Campbell, M. (2003). The productivity and skills challenge. Industrial and Commercial Training, 35(3), 99-103. http://dx.doi.org/10.1108/00197850310470311

Goodman, S. A., \& Svyantek, D. J. (1999). Person-organization fit and contextual performance: do shared values matter, Journal of Vocational Behavior, 55(2), 254-275. http://dx.doi.org/10.1006/jvbe.1998.1682

Green, K., Medlin, B., \& Whitten, D. (2004). Developing optimism to improve performance: an approach for the manufacturing sector. Industrial Management \& Data Systems, 104(2), 106-114. http://dx.doi.org/10.1108 /02635570410522071

Griffin, M. D., Jones, B. A. P., \& Spann, M. S. (2008). Knowledge vs. Certification: which is the Premier Emphasis for Gen Y Business Students? International Journal of Business Research, 8(4), 61-69.

Grinevica, L., Rivza, B., \& Kovalevs, R. (2015). Youth social inclusion trends in the Latvian labour market. Socialiniai tyrimai / Social Research. 1 (37), 57-66.

Guinipero, L., Handfield, B. R., \& Eltantawy, R. (2006). Supply management evolution: key skill sets for supply manager of the future. International journal of Operations and Production Management, 26(7), 822-844. http://dx.doi.org/10.1108/01443570610672257

Hatch, M. J., \& Cunliffe, A. L. (2006). Organization Theory. Modern, Symbolic, and Postmodern Perspectives. Oxford, New York.

Hancock, D. R. (2007). Effects of performance assessment on the achievement and motivation of graduate students. Active Learning in Higher Education, 8(219), 219-231. Doi: 10.1177/1469787407081888. http://alh.sagepub.com/cgi/content/ abstract/8/3/219 http://dx.doi.org/10.1177/1469787407081888

Katz, R. L. (1974). Skills of an effective administrator. Harvard Business Review, September-October, 90-102.

Kurekova, L., Haita, C., \& Beblavy, M, (2013). Conceptualizing Low-Skillness: A New Approach. Sociologia, 45(3).

de Lange,M., Gesthuizen, M., \& Wolbers, M. H. J. (2014). Youth Labour Market Integration across Europe. The impact of cyclical, structural, and institutional characteristics. European Societies, 16(2), 194-212. http://dx.doi.org/10.1080/ 14616696.2013.821621

Leonard, N. H., Beauvais, L. L., \& Scholl, R. W. (1999). Work motivation: The incorporation of self-concept based processes. Human Relations, 52, 969-998. http://dx.doi.org/10.1177/001872679905200801

Ling, H., \& Venesaar, U. (2015). Enhancing Entrepreneurship Education in Engineering Students to Increase Their Metacognitive Abilities: Analysis of Student Self-Assessments. Inzinerine Ekonomika-Engineering Economics, 26(3), 333-342. Doi: http://dx.doi.org/10.5755/j01.ee.26.3.5283

Litos, Ch., I., \& Moustaki, V. S. (2007). Experimental evaluation of executive skills in an EU country. Journal of Leadership Studies, 1(2), 33-52. http://dx.doi.org/10.1002/jls.20014

Locke, E. A., \& Latham, G. P. (1990). Work Motivation and satisfaction: Light at the end of the tunnel. American Psychological Science, 1(4), 240-246. http://dx.doi.org/10.1111/j.1467-9280.1990.tb00207.x

Machin, S., McIntosh, S., Vignoles, A., \& Viitanen, T. (2001). Basic Skills, Soft Skills and Labour Market Outcomes: Secondary analysis of the National Child Development Study, DfEE RR250, DfEE, London, http://webarchive.nationalarchives.gov.uk/20130401151715/http://www.education.gov.uk/publications/eOrderingDownl oad/RB250.pdf

Maslow, A. H., (1967). A theory of metamotivation: the biological rooting of the value-life". Journal of Humanistic Psychology, 7, 143-153. http://dx.doi.org/10.1177/002216786700700201

Motowidlo, S. J. (2003). Job performance. Handbook of psychology, 3, 39-53. http://dx.doi.org/10.1002/ 0471264385.wei1203

Peterson, T. O., \& Van Fleet, D. D. (2004). The ongoing legacy of R. L. Katz, an updated typology of management skills. Management Decision, 42(10), 1297-1308. http://dx.doi.org/10.1108/00251740410568980

Runiewicz-Wardyn, M. (2014). Geographic and Technological Pattern of Knowledge Spillovers as Evidenced by Technical Universities in CEE Countries. Inzinerine Ekonomika-Engineering Economics, 25(4), $466-473$. http://dx.doi.org/10.5755/j01.ee.25.4.3758

Shoura, M. M., \& Singh, A. (1999). Motivation parameters for engineering managers using Maslow's theory. Journal of Management in Engineering, 15(5), 44-55. http://dx.doi.org/10.1061/(ASCE)0742-597X(1999)15:5(44)

Stretton, S. (1994). Maslow and the modern public servant: A Lateral approach to performance and integrity in the public sector work environment. Australian Journal of Public Administration, 53(2), 144-151. http://dx.doi.org/10.1111/j. 1467-8500.1994.tb01870.x

Ruban, L. M., McCoach, D. B., McGuire, J. M., \& Reis, S. M. (2003). The Differential Impact of Academic Self-Regulatory Methods on Academic Achievement among University Students with and Without Learning Disabilities. Journal of Learning Disabilities, 36(3), 268-284. http://dx.doi.org/10.1177/002221940303600306

Trank, C. Q., \& Rynes, S. L. (2003). Who moved our cheese? Reclaiming professionalism in business education. Academy of Management Learning and Education, 2(2), 189-205. http://dx.doi.org/10.5465/AMLE.2003.9901678 
Vilmante Kumpikaite-Valiuniene, Ewa Glinska, Imran Aslan, Antonio Mihi Ramirez. Students' Attitude to Job...

Wahba, M. A., \& Bridwell, L. G. (1976). Maslow Reconsidered: A Review of Research on the Need Hierarchy Theory. Organisational Behaviour and Human Performance, 15, 212-240. http://dx.doi.org/10.1016/0030-5073(76)90038-6

Whetten, D. A., \& Cameron, K. S. (2002). Developing management skills, 5th ed., Englewood Cliffs, NJ: Prentice Hall.

World Bank (2015). http://data.worldbank.org/indicator/SL.UEM.1524.ZS

Xanthopoulou, D., Bakker, A. B., Heuven, E., Demerouti, E., \& Schaufeli, W. B. (2008). Working in the sky: a diary study on work engagement among flight attendants. Journal of Occupational Health Psychology, 13(4), 345-356. http://dx.doi.org/10.1037/1076-8998.13.4.345

The article has been reviewed.

Received in November 2015; accepted in April, 2016. 